\title{
Antigenotoxic Activity of Rumput Mutiara (Hedyotis corymbosa L.) Ethanolic Extract on Cyclophosphamide- Induced Mice
}

\author{
Yoce Aprianto $^{1}$, Asri Mega Putri ${ }^{1}$, Hilyatul Fadliyah ${ }^{1}$, Retno Murwanti ${ }^{3}$, \\ Edy Meiyanto ${ }^{1,2 *}$
}

\author{
${ }^{1}$ Cancer Chemoprevention Research Center, Faculty of Pharmacy, Universitas Gadjah Mada, Indonesia \\ ${ }^{2}$ Department of Pharmaceutical Chemistry, Faculty of Pharmacy, Universitas Gadjah Mada, Indonesia \\ ${ }^{3}$ Department of Pharmacology and Clinical Pharmacy, Faculty of Pharmacy, Universitas Gadjah Mada, Indonesia
}

\begin{abstract}
Exposure to relative chemicals has been shown to induce a genotoxic effect that can be observed through formation of micronucleus (MN) in polychromatic erythrocythes (PCE). Rumput Mutiara or Hedyotis corymbosa L. ethanolic extract (HcEE) is known to contain ursolic acid as major compound that possesses antigenotoxic activity on HepG2 cells. This study exerts in vivo approach aiming to evaluate the antigenotoxic effects of $\mathrm{HcEE}$ on cyclophosphamide (CP)-induced male Swiss mice. The ursolic acid on HcEE was determined by using thin layer chromatography with silica gel as stationary phase and chloroform-aceton (9:1) as mobile phase. The antigenotoxic activity was carried out by in vivo micronucleus test. Twenty four adult mice were equally divided into seven groups. Group I: control (untreated); group II: Na-CMC 0.5\%; group III: CP $50 \mathrm{mg} / \mathrm{kg}$ BW; group IV: CP+HcEE $250 \mathrm{mg} / \mathrm{kg}$ BW; group V: CP+HcEE $500 \mathrm{mg} / \mathrm{kg} \mathrm{BW}$; group VI: CP+HcEE $1000 \mathrm{mg} / \mathrm{kg}$ BW; group VII: HcEE $1000 \mathrm{mg} / \mathrm{kg}$ BW. HcEE were given for seven days, while CP was administered on the last two days. On the seventh day, the peripheral blood from all mice were collected, smeared, and then stained with Giemsa. The frequencies of MNPCEs and \%PCEs were evaluated. Molecular docking was performed to know the interaction between ursolic acid and CYP3A4 by using PLANTS software. There was similar hRF spot between HcEE with ursolic acid standard reference indicated that the extract almost positively contain ursolic acid. HcEE reduced MNPCEs significantly compared to CP group $(p<0.05)$ and combination of CP with HcEE showed reduction of \%PCEs $(p<0.05)$. Based on molecular docking analysis, ursolic acid gave lower docking score than CP against CYP3A4 (PDB ID: 2VOM) and similar binding site on amino acid residues Ala 448, Ile 369, Thr 309, and Val 3I3. All of these data suggest that HcEE perform protective effect against $\mathrm{CP}$-induced genotoxicity.
\end{abstract}

Keywords: Antigenotoxic, Hedyotis corymbosa L., cyclophosphamide, micronucleus, molecular docking

\section{INTRODUCTION}

Over exposure of reactive chemicals from food, air, water, or from metabolic products to human body has been shown to induce a genotoxic effect through DNA damage (Wogan, et al., 2004). Generally, DNA damage is triggered by ROS (Reactive Oxygen Species) produced by endogenous metabolites or exogenous chemicals that are activated by metabolism within cells (Bont and Larebeke, 2004). DNA damage is the beginning of mutation and cancer incidence which need to pay extra attention for the prevention. Unfortunately, the radical species may come from some particular drugs which essential to cure cancer, such as chemotherapeutic agents (Higuchi, 2003). In some cases, the use of chemotherapeutic agent rises cellular damage leading to new cancer clone. Such kind of these chemotherapeutic agents have characteristic as alkylating agent that reactively forming the covalent bound with DNA by which ROS as its the intermediate form. Cyclophosphamide is one of the chemotherapeutic agents whose exerts the same mechanism (McCarroll, et al., 2008). Nonetheless, take into account that chemotherapeutic agents are important in cancer therapy it is necessary to find ways for diminishing the genotoxic effects.

*Corresponding author e-mail: edy_meiyanto@ugm.ac.id 
Actually radical species can be neutralized naturally by antioxidant enzymes, e.g., SOD (superoxide dismutase), GPX (glutathione peroxidase), GR (glutathione reductase), HO (heme oxgenase), catalase, etc. (Bhattacharyya, et al., 2014). However, the constitutive expression of enzymes cannot neutralize properly the abundant ROS (Wang, et al., 2011). Therefore the administration of antioxidants from external sources is a strategic way to overcome this condition.

The purpose of this study is to evaluate the activity of Rumput Mutiara or Hedyotis corymbosa L. ethanolic extract (HcEE) in overcoming genotoxic effects of cyclophosphamide (CP) through in vivo and molecular docking study. In vitro study revealed that methanolic extract of Hedyotis corymbosa $\mathrm{L}$. present high antioxidant activity that responsible for counteracting free radicals and inhibiting ROS formation (Uttara, et al., 2009; Sasikumar, et al., 2010). Particularly, it is known to contain ursolic acid as the active compounds (Chen, et al., 2005). Beside antioxidant properties, the ursolic acid is also reported to exhibit chemopreventive and antimutagenic effect (Martin-Aragon, et al., 2001; Ramos, et al., 2008). Thus, HcEE can be predicted to possess activity as well as antigenotoxic agent.

\section{MATERIALS AND METHODS}

\section{Extract Preparation}

Wet herb of Hedyotis corymbosa were collected from Yogyakarta, Indonesia, then was determined at Biological Pharmacy Laboratory, UGM. The simplicia were blended to powder form then macerated with $96 \%$ ethanol $(1: 1)$ for three days and remacerated for two days. The macerate was dried using rotary evaporator on $40^{\circ} \mathrm{C}$. Identification of chemical compound in HcEE were monitored using TLC analysis by used ursolic acid as reference standard, chloroform: aceton $(9: 1 \mathrm{v} / \mathrm{v})$ as the mobile phase while the stationary phase is silica gel F254.

\section{Chemicals}

Cyclophosphamid (Kalbe), Aquades (Asia Lab), Na-CMC (Sigma), Giemsa staining (Aldrich),
Xylol (Aldrich), Entellan® Neu (Aldrich), Ethanol $96 \%$ (for technically use), and immersion oil (Aldrich).

\section{Animal}

Forty two Swiss male mice aged 6-7 weeks with 23-29 gram weight obtained from Health Research and Development Agency (Litbangkes) Ministry of Health Republic of Indonesia in Jakarta. Then the test animal was adapted for one week before treatment began (acclimatization). The test animals were divided into seven treatment groups consisting of six mice each (Table I). Each group of mice is placed in a plastic box that is different from the husk base, with room temperature around $23^{\circ}$ $25^{\circ} \mathrm{C}$ and humidity of $70-80 \%$.

\section{In Vivo Micronucleus Test}

In vivo micronucleus test was carried out based on the method developed by Krishna and Hayashi (2010). Briefly, all mice were divided into seven groups, as follow:

(a) Group 1: Untreated

(b) Group 2: Na-CMC 0.5\%

(c) Group 3: CP $50 \mathrm{mg} / \mathrm{kg}$ BW

(d) Group 4: HcEE $250 \mathrm{mg} / \mathrm{kg} \mathrm{BW}+\mathrm{CP} 50$ $\mathrm{mg} / \mathrm{kg} \mathrm{BW}$

(e) Group 5: HcEE $500 \mathrm{mg} / \mathrm{kg} \mathrm{BW}+\mathrm{CP} 50$ $\mathrm{mg} / \mathrm{kg} \mathrm{BW}$

(f) Group 6: HcEE $1000 \mathrm{mg} / \mathrm{kg} \mathrm{BW}+\mathrm{CP} 50$ $\mathrm{mg} / \mathrm{kg} \mathrm{BW}$

(g) Group 7: HcEE 1000 mg/kg BW

The treatment design is presented as shown as Table 1. All treatment groups were sampling peripheral blood through vein of tails at the 30 hours after giving CP. The blood specimens were made peripheral blood smear preparation on the microscope slides with smearing angle of $45^{\circ}$, then methanol was fixed for 15 minutes and after that stainined with Giemsa $10 \%$ in PBS pH 6.8 with incubation time 60 minutes. The preparation was cleaned using aquadest. After the preparation dried, preparation was closed by the cover slip using Entellen and observed the MNPCE, PCE, and NCE under microscope with 1000x magnification. 
Table I. In vivo test treatment design

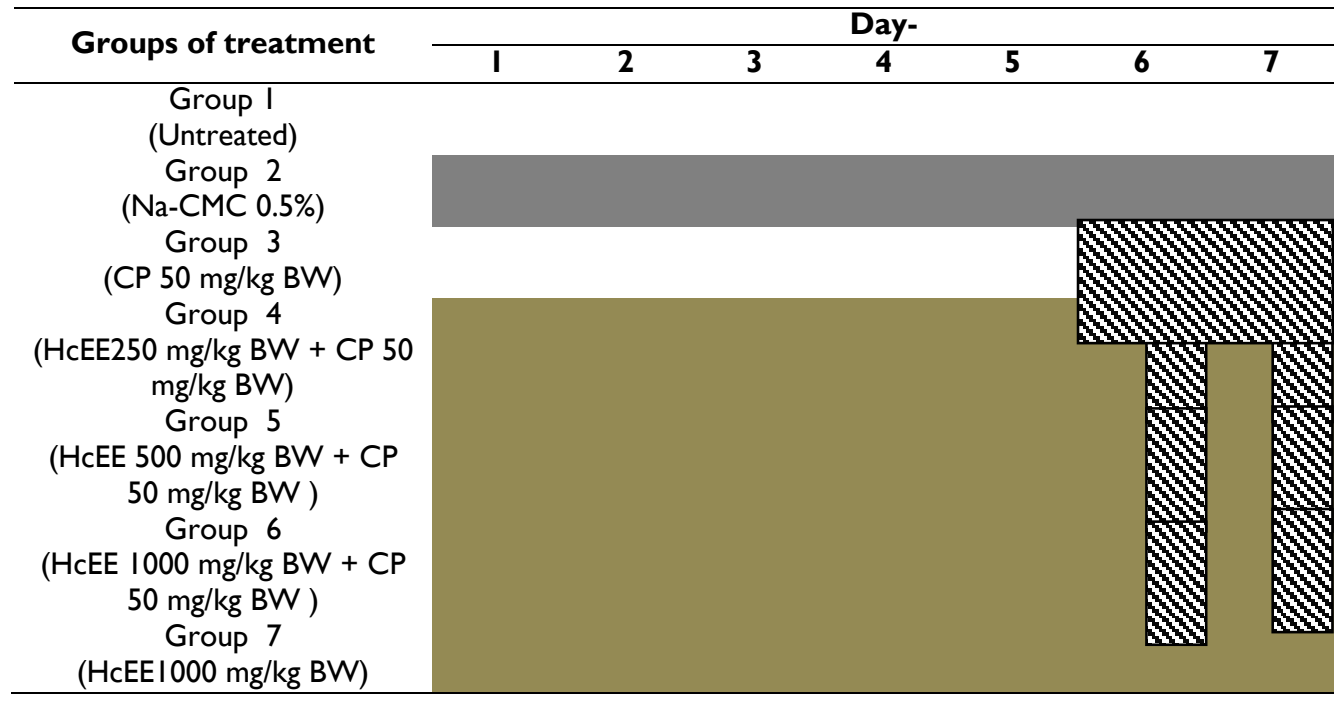

Explanation :

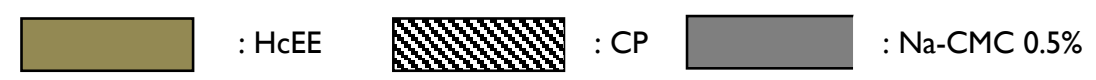

\section{Molecular Docking}

The Marvinsketch program was utilized to make 3D phalerin and YASARA software was used for protein target preparation. PLANTS software was used for docking. The target protein choosed was CYP3A4 and the test compound used was ursolic acid and cyclophosphamid. The ursolic acid and cyclophosphamide ligand are then tethered to a protein that has been removed by its native ligand using the PLANTS program. Output obtained declare the force of ligand-receptor interaction in the form of docking scores. Visualization of amino acid residues that interact with receptors can be observed in $3 \mathrm{D}$ and $2 \mathrm{D}$ through the MOE program version 2010.

\section{Data Analysis}

MNPCE observations were performed for every 2000 PCE cells, whereas \%PCE calculations were performed on every 2000 total PCE and NCE $(\mathrm{PCE}+\mathrm{NCE})$ cells. MNPCE will be colored purple after Giemsa staining and has one or more micronucleus, PCE is purple and has no micronucleus, while NCE is not purple. Furthermore, statistical tests conducted using SPSS version 21. Statistical test begins with the test of data normality using Kolmogorov Smirnov. After it is known that the data is normally distributed, parametric statistic test was done with one way ANOVA followed by post-hoc Tuckey HSD test using $95 \%$ confidence level to know the significance of group. In addition, calculations of DNA damage reduction were done based on Waters et al. (1990) with the following formula:

$$
\% \text { Reduction }=\frac{\mathrm{A}-\mathrm{B}}{\mathrm{A}-\mathrm{C}} \times 100
$$

Explanation :

A : average number of MNPCE due to single treatment of $\mathrm{CP}$

$B$ : average number of MNPCE due to treatment of $\mathrm{CP}$ and HcEE

$\mathrm{C}$ : average number of MNPCE due to untreated group

The result of molecular docking was docking score between ursolic acid-CYP3A4 and cyclophosphamide- CYP3A4. If docking score ursolic acid-CYP3A4 is lower than cyclophosphamide- CYP3A4, it show that ursolic acid which probably contained in the HcEE will be potential antigenotoxic agent. 


\section{RESULTS}

\section{Identification of HcEE Phytochemical Content}

The TLC profile of HcEE shows the presence of pink spots on visible light with the color intensity and hRf (60) which is similar to the ursolic acid standard reference (Fig. 1). Hedyotis corymbosa L. contains pentacyclic triterpenoids of ursolic acid and oleanolic acid; the difference between the two lies only in the methyl group in the $\mathrm{E}$ ring. This phenomenon causes difficulty of separating both with the TLC system. The system of isocratic eluents certainly cannot separate the two. Based on this result, the pink spot on the TLC profile of HcEE may be a combination of ursolic acid and oleanolate acid (Haryanti, 2008).

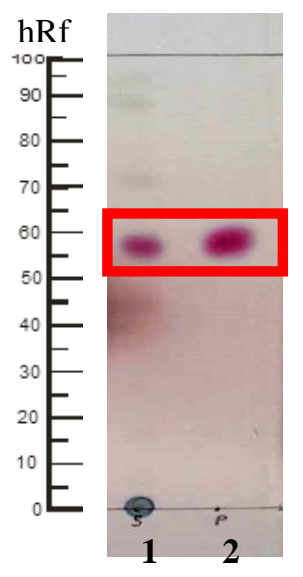

Figure I. Thin chromatography profile of HcEE. Elution was performed with chloroform: acetone (9: I $\vee / \vee$ ) as mobile phase. The numbers $\mathrm{I}$ and 2 respectively are $\mathrm{HcEE}$ and ursolic acid standards. The TLC plate after spraying with $10 \%$ of $\mathrm{H}_{2} \mathrm{SO}_{4}$ in ethanol was then heated to $110^{\circ} \mathrm{C}$ for 5 min showed the pink spots on visible light with a hRf value of 60.

\section{Determination of the Number of MNPCE and \%PCE of Peripheral Blood}

Based on the results of this study, the observation of the appearance of MNPCE, PCE, and NCE cells of peripheral blood smear in Swiss strains mice induced cyclophosphamide represented in Fig. 2. After Giemsa staining, MNPCE will be colored purple with micronucleus appearance on cytoplasm, while PCE is purple without micronucleus, and a gray NCE that can be observed under a light microscope. The number of MNPCE formed is a parameter of DNA damage. Observations of MNPCE, PCE, and NCE were performed on one blood smear per mice.

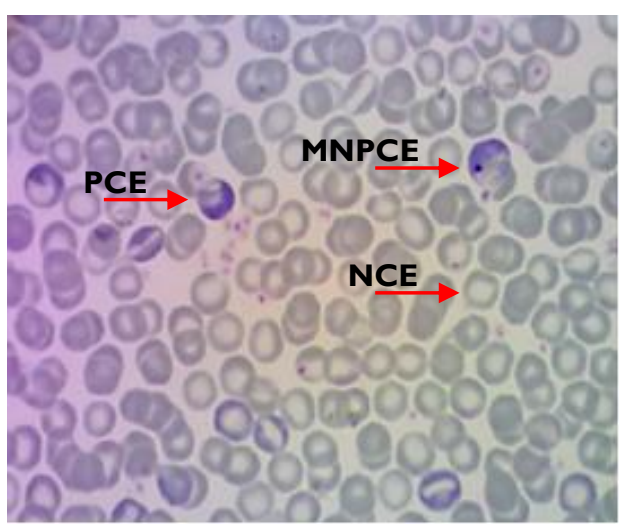

Figure 2. Representative of cell appearace on pheripheral blood under treatment. Giemsa staining was performed and observed through a $1000 x$ magnification light microscope (with immersion oil) and photographed using a digital camera. Red arrow ( $\longrightarrow$ ) showed each MNPCE, PCE, and NCE.

The control group of $50 \mathrm{mg} / \mathrm{kg} \mathrm{BW}$ of cyclophosphamide exhibit significantly the highest number of micronucleus (MNPCE) formation $(p<0.05)$ by $90.5 \pm 7.44$ (Table 2). This result suggests that cyclophosphamide has been shown to induce genotoxic effects. Animals tested with a single concentration of HcEE $1000 \mathrm{mg} / \mathrm{kg} \mathrm{BW}$ (high risk) performed the strongest decrease in MNPCE (1.50 \pm 0.65$)$. This phenomenon reveals that HcEE does not cause a genotoxic effect on its sole treatment. HcEE treatment with a variety of concentrations was shown to significantly decrease MNPCE against cyclophosphamide treatment. HcEE 250,500 , and $1000 \mathrm{mg} / \mathrm{kg} \mathrm{BW}$ were able to suppress the formation of MNPCE as a result of the cyclophosphamide induction at $35.5 \pm 3.80$; $6.50 \pm 1.85$; and $2.75 \pm 0.85$ (Fig. 3).

Then we observed the number of nucleated red blood cell (PCE) to evaluate the effect of HcEE on blood differentiation. The \% PCE parameter is the ratio of nucleated red blood cell used to assess the level of tested test substance given to the target cell. To measure the level of toxicity on bone marrow, then made minimal observations on 1000 total 
erythrocytes of peripheral blood (Krishna and Hayashi, 2000). Based on this study, the \%PCE increase that occurred at all HcEE treatment concentration $(250,500$, and $1000 \mathrm{mg} / \mathrm{kg} \mathrm{BW})$ were higher than in the cyclophosphamide treatment group. A single HcEE concentration of $1000 \mathrm{mg} / \mathrm{kg}$ BW also showed an increase in \%PCE $(7.36 \pm 0.92)$ (Table 2), so the HcEE used in this study was nontoxic to erythroblasts in its sole treatment and was able to normalize \%PCE.

\section{Molecular Docking}

Molecular docking test protocol is done by referring to Purnomo (2011) using PLANTS software. The molecular docking test against CYP3A4 showed that native ligand, cyclophosphamide, and ursolic acid docking scores were $-114 ;-74$; and -88 (Table 3 ). The lower the docking score, the compound is predicted to interact more potent with the target protein. The ursolic acid has a lower docking score compared to cyclophosphamide, so it is thought that ursolic acid more potent interacts than cyclophosphamide to CYP3A4 despite the docking score of ursolic acid is greater than native ligand.

Based on the $2 \mathrm{D}$ and $3 \mathrm{D}$ visualization results (Fig. 4), the interaction of ursolic acid with CYP3A4 is shown by the similarity of the binding sites with the native ligand in the amino acid residues Ala 448, Ile 369, Thr 309 and Val 313 through hydrophobic bonds, whereas cyclophosphamide may interact with CYP3A4 via the binding site on the Ile 369 and $\mathrm{Thr}$ 309 amino acid residues. Thus, the ursolic acid compound has a similar site attachment to more amino acid residues than between cyclophosphamide and native ligand.

Table 2. Number of MNPCE and \%PCE

\begin{tabular}{cccc}
\hline Groups & $\begin{array}{c}\text { Average of MNPCE } \pm \\
\text { S.E.M. }\end{array}$ & $\begin{array}{c}\text { Average of \%PCE } \pm \\
\text { S.E.M. }\end{array}$ & Reduction (\%) \\
\hline Untreated & $0.25 \pm 0.25 \mathrm{a}, \mathrm{b}$ & $5.04 \pm 0.6 \mathrm{I}$ & - \\
Na-CMC 0.5\% & $1.75 \pm 1.03 \mathrm{a}, \mathrm{b}$ & $3.24 \pm 0.60$ & - \\
CP & $90.50 \pm 7.44 \mathrm{~b}$ & $2.81 \pm 0.30$ & - \\
HcEE 250+CP & $35.50 \pm 3.80 \mathrm{a}$ & $10.24 \pm 5.1 \mathrm{I}$ & 60.94 \\
HcEE 500+CP & $6.50 \pm 1.85 \mathrm{a}, \mathrm{b}$ & $3.53 \pm 0.32$ & 85.29 \\
HcEE 1000+CP & $2.75 \pm 0.85 \mathrm{a}, \mathrm{b}$ & $3.72 \pm 0.31$ & 98.87 \\
HcEE 1000 & $1.5 \pm 0.65 \mathrm{a}, \mathrm{b}$ & $7.36 \pm 0.92$ & - \\
\hline
\end{tabular}

Explanation $=$ a: $p<0,05$ to $C P$; $\mathrm{b}: p<0,05$ to HcEE $250+C P$ group \% $\mathrm{PCE}$ is $\mathrm{PCE} /(\mathrm{PCE}+\mathrm{NCE})$ ratio

(a)

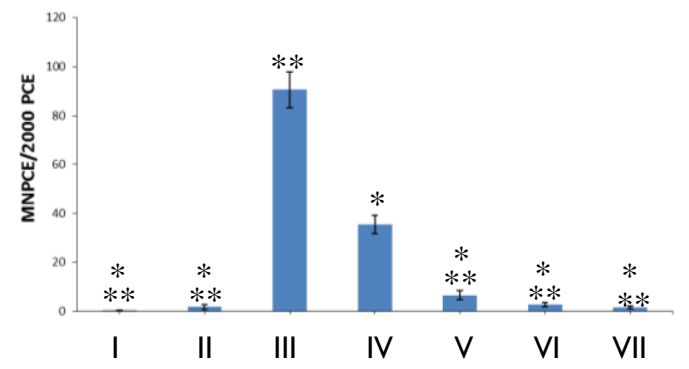

(b)

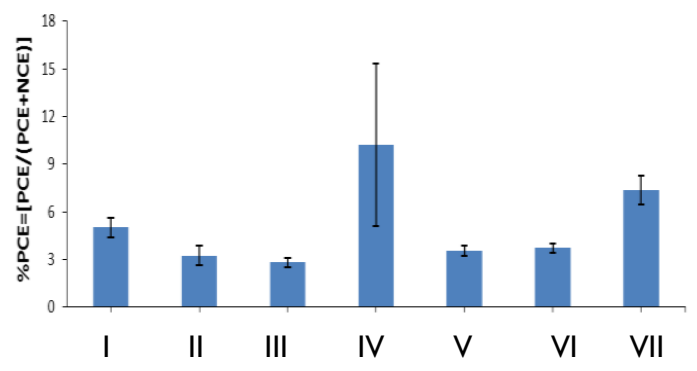

Figure 3. Effect of HcEE on the peripheral blood profile. Peripheral blood smear was observed under a $1000 x$ magnification light microscope (immersed oil), then calculated (a) MNPCE/ 2000 PCE and (b) \% PCE $=[P C E /(P C E+$ NCE)] with labels I : untreated, II : Na-CMC 0.5\%, III : CP, IV : HcEE $250 \mathrm{mg} / \mathrm{kg} \mathrm{BW} \mathrm{+} \mathrm{CP,} \mathrm{V:} \mathrm{HcEE} 500 \mathrm{mg} / \mathrm{kg} \mathrm{BW} \mathrm{+}$ $\mathrm{CP}, \mathrm{VI}: \mathrm{HcEE} 1000 \mathrm{mg} / \mathrm{kg}$ BW + CP, VII : HcEE $1000 \mathrm{mg} / \mathrm{kg}$ BW. The statistical test was performed using SPSS version 21 software with one way ANOVA method followed by Post Hoc Tuckey Test $(p<0,05)$. The results are presented in the mean $\pm S E(n=4)$. Interconnection significance is indicated by asterisks $(*)$ and $(* *)$ on the graph. Sign (*) shows significance to control of CP $50 \mathrm{mg} / \mathrm{kg}$ BW and sign (**) indicates significance to treatment group HcEE 250 $+\mathrm{CP} 50 \mathrm{mg} / \mathrm{kg}$ BW. 
Table 3. Score docking data of CYP3A4 target protein (2V0M)

\begin{tabular}{llc}
\hline Ligands & Docking score & RMSD \\
\hline Ketoconazole (native ligand) & -114 & $1.50 \AA$ \\
Cyclophosphamide & -74 & \\
Ursolic acid & -88 & \\
\hline
\end{tabular}

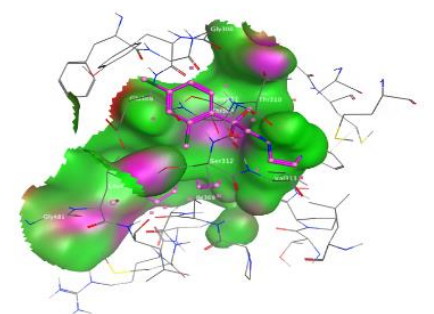

(a)

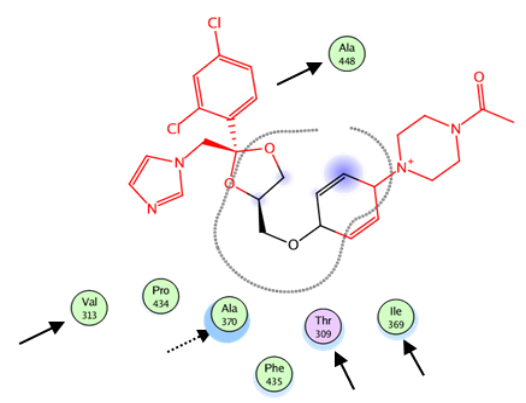

(a)

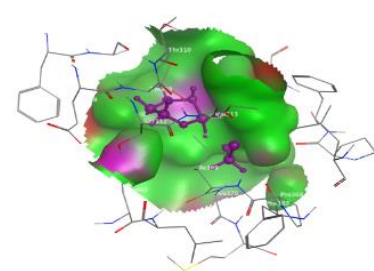

(b)

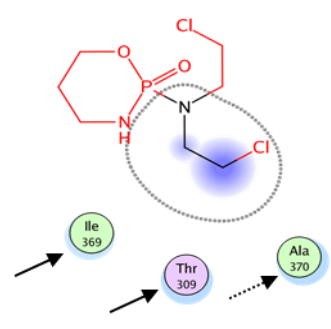

(b)

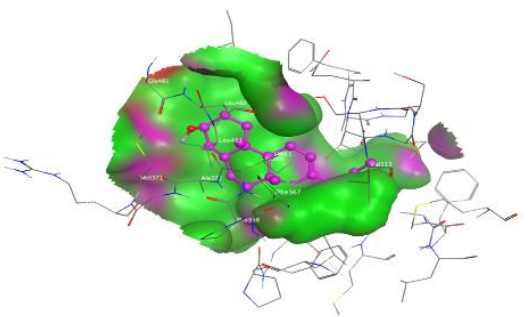

(c)

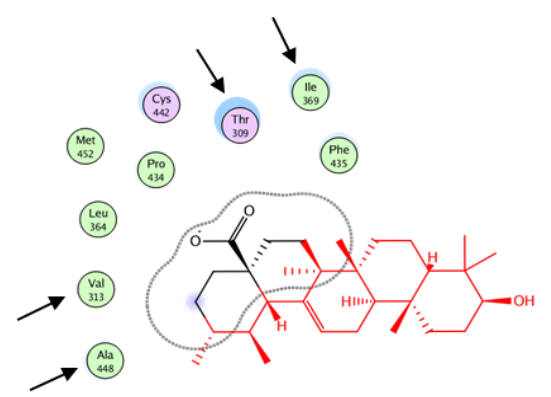

(c)

Figure 4. Visualize 3D and 2D interactions between ligand and target protein CYP3A4 (PDB ID: 2V0M) using MOE 2010 applications. 3D interaction visualization (top image) and 2D (bottom image). The compound ketoconazole (native ligand) (a), cyclophosphamide (b), and ursolic acid (c) have a binding site on the same amino acid residues. The sign $\longrightarrow$ denotes the similarity to the 370 amino acid residue. The sign $\rightarrow$ denotes residual similarity to the amino acids Ala 448, lle 369, Thr 309, and Val 313 with the native ligand.

\section{DISCUSSION}

This study was conducted to evaluate the potential of $\mathrm{HcEE}$ as an antigenotoxic agent in overcoming the effects of DNA damage. The active compound suspected of having antigenotoxic activity from rumput mutiara (Hedyotis corymbosa L.) is ursolic acid. Rumput mutiara is known to contain triterpenoids of ursolic acid and oleanolate (Khastgir, et al., 1960). The extraction process was carried out using 96\% ethanol solvent because the active compound of ursolic acid is a relatively non-polarized triterpenoid group compound.
HcEE is reported to have cytotoxic activity against some cancer cells in vitro. Suparman (2008) and Lee, et al. (2011) showed that HcEE was able to inhibit the proliferation of colon cancer cells WiDr and COLO 205, Hep3B liver cancer, and lung cancer H460. Other research from Chen, et al. (2006) mentioned that ursolic acid is active in MCF-7 cells with IC50 $4.7 \mu \mathrm{g} / \mathrm{mL}$, whereas oleanolic acid has very weak cytotoxic activity, even up to a concentration of $20 \mu \mathrm{g} / \mathrm{mL}$ gave only $30 \%$ inhibition of cell viability. The ursolic acid is also reported to have an antigenotoxic effect on HepG2 in vitro (Ramos, et al., 2008). Based on these data, it can be predicted that ursolic acid plays a more dominant role than other compounds 
contained in rumput mutiara herbs in mediating the antigenotoxic effects of HcEE.

The animals for testing used in this study were mice with the consideration that granules mast cells in mice blood were found to be fewer than mice, making them more easily observed in the scoring process and would provide false positives (Jamura, et al., 2001; Pascoe and Gatehouse, 1986). Furthermore, data from The Collaborative Study Group for the Micronucleus Test (1986) mentioned that in general male mice are more sensitive than female mice to micronucleus induction, so in this study also used male mice.

This study showed that in the treatment of cyclophosphamide with a concentration of 50 $\mathrm{mg} / \mathrm{kg} \mathrm{BW}$ was the most significant increase in the amount of MNPCE that was formed. Meanwhile, in the treatment of HcEE concentrations of 250, 500 , or $1000 \mathrm{mg} / \mathrm{kg}$ BW with cyclophosphamide $50 \mathrm{mg} / \mathrm{kg} \mathrm{BW}$, there was a significant decrease in frequency of MNPCE per 2000 PCE cells compared with cyclophosphamide control after one-way ANOVA with 95\% confidence level. At the highest concentration, HcEE was able to decrease MNPCE up to 32.91 times and with a concentration of $500 \mathrm{mg} / \mathrm{kg}$ BW lowered the number of MNPCE by 13.92 times.

The results of this study can be compared with previous research by Sugiyanto (2014) who tested antigenotoxic activity from secang ethanolic extract (Caesalpinia sappan L.) concentration 500 $\mathrm{mg} / \mathrm{kg} \quad$ BW and $1000 \mathrm{mg} / \mathrm{kg}$ BW with cyclophosphamide treatment $50 \mathrm{mg} / \mathrm{kg}$ BW. Furthermore, at a concentration of $500 \mathrm{mg} / \mathrm{kg} \mathrm{BW}$, the secang wood extract reduced the MNPCE count by 3.5 times and at a concentration of 1000 $\mathrm{mg} / \mathrm{kg}$ BW could significantly decrease MNPCE by 20 times compared with cyclophosphamide control. Another study by Shabrina (2015) under the same treatment condition mentioned that papaya leaf ethanolic extract (Carica papaya L.) could decrease the number of MNPCE / 1000 PCE by 2.25 times at concentration of $500 \mathrm{mg} / \mathrm{kg} \mathrm{BW}$ and 2.8 times at concentration highs.

Genotoxic effects of cyclophosphamide arise after metabolism into active metabolites, namely phosphoramide mustard and acrolein. The genotoxic cyclophosphamide metabolite will attack the $\mathrm{N} 7$ atom from the guanine base residue on the DNA chain. The process will increase the crosslinking of the two DNA strands together (Brulikova, et al., 2012). The presence of these crosslinks will disrupt the function of nucleic acids and DNA synthesis and lead to the formation of micronucleus and cell death (Crook, et al., 1986; Tripathi and Jena, 2009; Bryce, et al., 2010). HcEE is known to contain triterpenoid compounds of ursolic acid which are believed to capture free radicals of cyclophosphamide metabolites. The content of ursolic acid in HcEE is thought to increase the levels of enzymatic and nonenzymatic antioxidants (GSH) and inhibit cytochrome P450 (Liu, 1995; Martin-Arago, et al., 2001; Saravanan, et al., 2005). However, the mechanism of ursolic acid in influencing the process of repairing DNA damage is not known for certain (Ferguson, 2001; Ferguson, et al., 2004).

Treatment of cyclophosphamide $50 \mathrm{mg} / \mathrm{kg}$ BW caused a decrease in \%PCE compared with other treatment groups. This is in accordance with the research of Jones, et al. (2001) that cyclophosphamide decreases the PCE ratio in peripheral blood. In the treatment of $\mathrm{HcEE}$ concentrations of 250,500 , and $1000 \mathrm{mg} / \mathrm{kg} \mathrm{BW}$, it has been shown to increase the value of \% PCE in peripheral blood smear measurements observed on a single slide microscope. Increased \%PCE parameters indicate a possible increase in erythrocytes production due to loss of adult erythrocytes (NCE), whereas a decrease in \%PCE reflects a younger erythrocyte reshuffle (PCE) that has direct implications for erythrocyte production in bone marrow (Nathoo and Marshall, 2002). HcEE $250 \mathrm{mg} / \mathrm{kg}$ BW gave the highest \%PCE among other treatment doses, although the treatment did not give significant difference to the doses of 500 or $1000 \mathrm{mg} / \mathrm{kg}$ BW based on statistical tests.

In this research, molecular docking test was done to find out the possibility of interaction of ursolic acid compound with CYP34A target protein. Docking is a tethering interaction between ligands and proteins used to predict ligand position and orientation when bound to protein receptors (Girija, et al., 2010). Test ligand used in the form of ursolic acid and cyclophosphamide. While the native ligand is ketoconazole which is a powerful antifungal inhibitor of CYP3A4 (Ekroos and Sjögren, 2006). CYP3A4 was chosen as the target 
protein because it is one of the 450 cytochromes activating cyclophosphamide (Anonymous, 2013).

When compared with cyclophosphamide, ursolic acid has a lower docking score, so it can be estimated that ursolic acid more potent interacts with CYP3A4 than cyclophosphamide. This result is reinforced by the visualization of interactions that can be observed in 3D and 2D in the receptor ligand-receptor area can only show hydrophobic and hydrogen bonds. Hydrophobic bonds play a role in determining ligand stability to receptors (Arwansyah et al., 2014). A greater number of hydrogen bonds show a greater interaction between ligand and receptor (Sarmoko, 2008). In the observation of interaction visualization showed the similarity of bond sites with native ligand on amino acid residues Ala 448, Ile 369, Thr 309, and Val 313, while cyclophosphamide has fewer similar sites, ie only on amino acid residue Ile 369 and Thr 309. Thus, it can be concluded that ursolic acid can interact better with CYP3A4 target protein than cyclophosphamide.

Overall, the results of this study have shown the antigenotoxic effect of HcEE with parameters of the amount of MNPCE and\% PCE in cyclophosphamide induced mouse assay and computational method approach through molecular docking to see the interaction between ursolic acid and cyclophosphamide to CYP3A4 target protein. Further research is needed to determine dose optimization to ensure therapeutic effectiveness and development of appropriate dosage formulations for antigenotoxic agents.

\section{CONCLUSION}

ERM 250, 500, and $1000 \mathrm{mg} / \mathrm{kg}$ BW were shown to provide antigenotoxic activity as indicated by a significant decrease in the number of MNPCE/2000 PCE and have a tendency to increase the \%PCE value in Swiss straincyclophosphamide induced mice. Through the computational approach it is known that the ursolic acid compound can interact on CYP3A4 (PDB ID: $2 \mathrm{~V} 0 \mathrm{M})$ based on the lower docking score parameter (-88) than cyclophosphamide (-74) and the similarity of the connective site with native ligand in the amino acid residue Ala 448, Ile 369, Thr 309, and Val 313 on the molecular docking test.

\section{ACKNOWLEDGMENT}

We express our gratitute to Directorate General of Learning and Student Affairs, Ministry of Research, Technology and Higher Education for the grant research under Student Creativity Program.

\section{REFERENCES}

Anonymous, 2013, Cyclophosphamide for Injection and Tablets Package Insert, Deerfield: Baxter Healthcare Corporation.

Arwansyah, Ambarsari, L. and Sumaryada,T.I., 2014, Simulasi docking senyawa kurkumin dan analognya sebagai inhibitor reseptor androgen pada kanker prostat, Curr. Biochem., I(I), II-I9.

Bhattacharyya, A., Chattopadhyay, R., Mitra, S. and Crowe, S.E., 2014, Oxidative Stress: An Essential Factor in the Pathogenesis of Gastrointestinal Mucosal Diseases, Physiol. Rev., 94(2), 329-354.

Bont, R. D. and van Larebeke, N., 2004, Review: Endogenous DNA Damage in Humans: A Review of Quantitative Data, Mutagenesis, 19(3), 169-185.

Brulikova, L., Hlavac, J. and Hradil, P., 2012, DNA Interstrand Cross-linking Agents and Their Chemotherapeutic Potential, Curr. Med. Chem., 19(3), 364-385.

Bryce, S.M., Shi, J., Nicolette, J., Diehl, M., Sonders, P., Avlasevich, S., et al., 2009, High Content Flow Cytometric Micronucleus Scoring Method is Applicable to Attachment Cell Lines, Environ. Mol. Mutagen., 5 I (3), 260266.

Chen, Y.H., Chang, F.R., Wu, C.C., Yen, M.H., Liaw, C.C., Steelman, L.S., et al., 2005, New Cytotoxic 6-oxigenated 8,9-hedyotiscone ac, from Hedyotis biflora, Planta Medica, 72(I), 75-78.

Chen, Y., Guo, Y., Ge, X., Itoh, H., Watanabe, A., Fujiwara, T., et al, 2006, Elevated Expression and Potential Roles of Human Sp5, a Member of Sp Transcription Factor Family, in Human Cancers, Biochem. Biophys. Res. Commun., 340(3), 758-766. 
Crook, T.R., Souhami, R.L. and McLean, A.E., 1986, Cytotoxicity, DNA Cross-linking, and Single Strand Breaks Induced by Activated Cyclophosphamide and Acrolein in Human Leukemia Cells, Cancer Res., 46(10), 50295034.

Ekroos, M. and Sjögren, T., 2006, Structural Basis for Ligand Promiscuity in Cytochrome P450 3A4, Proc. Natl. Acad. Sci. USA, I 03(37), |3682- 3687.

Ferguson, L.R., 200I, Role of Plant Polyphenols in Genomic Stability, Mutat. Res., 475(I-2), 89-III.

Ferguson, L.R., Philpot, M. and Karunasinghe, N., 2004, Dietary Cancer and Prevention Using Antimutagens, Toxicology, I98(I-3), I47159.

Girija, C.R., Karunakar, P., Poojari, C.S., Begum, N.S. and Syed, A.A., 2010, Molecular Docking Studies of Curcumin Derivative with Multiple Protein Targets for Procarcinogen Activating Enzyme Inhibition, J. Proteomics Bioinform., 3(6), 200-203.

Higuchi Y, 2003, Chromosomal DNA Fragmentation in Apoptosis and Necrosis Induced by Oxidative Stress, Biochem. Pharmacol., 66(8), I527-1535..

Jamura, M.C., Grodzkia, A.C.G., Morenob, A.N., De Mellob, L.C., Pastora, M.V.D. and Olivera, C., 200I, Identification and Isolation of Rat Bone Marrow-derived Mast Cells Using the Mast Cell-specific Monoclonal Antibody, J. Histochem. Cytochem., 49(2), 219-228.

Jones, E., Fox, V., Elliott, B.M. and Moore, N.P., 200I, The Mutagenic Potential of Acetonitrile in the Bone Marrow and Peripheral Blood of the Mouse, Mutagenesis, I 6(2), I5 I-154.

Khastgir, H., Sengupta, S.K. and Sengupta, P., 1960, Note on the Constituents of the Indian Medicinal Plant Oldenlandia corymbosa Linn., J. Am. Pharm. Assoc., 49(8), 562-563.

Krishna, G. and Hayashi, M., 2000, In vivo Rodent Micronucleus Assay: Protocol, conduct and Data Interpretation, Mutat. Res., 455(I-2), I55-166.
Liu, J., 1995, Pharmacology of Oleanolic Acid and Ursolic Acid, J. Ethnopharmacol., 49(2), 5768.

Lee, H.Z., Bau, D., Kuo, C.L., Tsai, R.Y., Hen, Y.C. and Chan, Y.H., 20II, Clarification of the Phenotypic Characteristics and Anti-tumor activity of Hedyotis diffusa, Am. J. Chin. Med., 39(I), 20I-2I3.

Martin-Aragon, S., de las Heras, B., Sanchez-Reus, M.I. and Benedi, J., 200I, Pharmacological Modication of Endogenous Antioxidant Enzymes by Ursolic Acid on TetrachlorideInduced Liver Damage in Rats and Primary Cultures of Rat Hepatocytes, Exp. Toxicol. Pathol., 53(2-3), 199-206.

McCarroll, N., Keshava, N. and Cimino, M., 2008, An Evaluation of the Mode of Action Framework for Mutagenic Carcinogens Case Study: Cyclophosphamide, Environ. Mol. Mutagen., 49(2), ||7-|3|.

Nathoo, S.A. and Marshall, M.V., 2002, Genotoxic Assessment of BriteSmile Whitening Procedure $\mathrm{Gel}$ in the Mouse Micronucleus test, Proceeding, IADR.

Pascoe, S. and Gatehouse, D., 1986, The Use of a Simple Haematoxylin and Eosin Staining Procedure to Demonstrate Micronuclei within Rodent Bone Marrow, Mutat. Res., 164(4), 237-43.

Purnomo, H., 20II, Kimia komputasi: molecular docking PLANTS, Yogyakarta: Pustaka Pelajar.

Ramos A.A., Lima C.F., Pereira M.L., FernandesFerreira M. and Pereira-Wilson C., 2008, Antigenotoxic Effects of Quercetin, Rutin and Ursolic Acid on HepG2 Cells: Evaluation by the Comet Assay, Toxicol. Lett., 177, 66-73.

Saravanan, R., Viswanathan, P. and Pugalendi, K.V., 2005, Protective Effect of Ursolic Acid on Ethanol-mediated Experimental Liver Damage in Rats, Life Sci., 78(7), 7/3-7/8.

Sarmoko, 2008, Uji sitotoksik ekstrak etanolik daun sirihan (Piper aduncum L.) terhadap sel kanker payudara dan prediksi interaksi senyawa calkon terhadap reseptor berdasarkan molecular docking, Essay, Universitas Gadjah Mada, Yogyakarta. 
Shabrina, B.A., 20I5, Efek Antigenotoksik Ekstrak Etanolik Daun Pepaya (Carica Papaya L.) pada Mencit (Mus musculus) Galur Swiss Terinduksi Siklofosfamid Melalui Mammalian in vivo Micronucleus Test, Essay, Universitas Gadjah Mada, Yogyakarta.

Sugiyanto, R., 2014, Menakar Potensi Antigentotoksik Kayu Secang (Caesalpinia Sappan L.) dalam Prevensi Kerusakan DNA Melalui MNPCE Assay in vivo, Essay, Universitas Gadjah Mada, Yogyakarta.

Suparman, 2008, Efek ekstrak etanolik rumput mutiara (Hedyotis corymbosa L.) terhadap aktivitas sitotoksik doksorubicin pada sel kanker kolon WiDr, Thesis, Universitas Gadjah Mada, Yogyakarta.

The Collaborative Study Group for the Micronucleus Test, CSGMT., 1986, Sex Difference in the Micronucleus Test, Mutat. Res., 172 (2), $15 \mid-163$.

Tripathi, D.N. and Jena, G.B., 2009, Intervention of Astaxanthin Against Cyclophosphamideinduced Oxidative Stress and DNA
Damage: A Study in Mice, Chem. Biol. Interact., I 80(3), 398-406.

Uttara, B., Singh, A.V., Zamboni, A.V. and Mahajan, R.T., 2009, Oxidative Stress and Neurodegenerative Diseases: A Review of Upstream and Downstream Antioxidant Therapeutic Options, Curr. Neuropharmacol., 7(I), 65-74.

Wang, S. H., Li, Q., Deng, Z.H., Ji, X., Jiang, X., Ge, $X$. , et al., 20II, Neanthes japonica (lznka) Fibrinolytic Enzyme Reduced Cerebral Infarction, Cerebral Edema and Increased Antioxidation in Ratmodels of Focal Cerebral Ischemia, Neurosci. Lett., 489(I), 16-19.

Waters, M.D., Brady, A.L., Stack, H.F. and Brockman, H.E., 1990, Antimutagenicity Profiles for Some Model Compounds, Mutat. Res., 238(I), 57-85.

Wogan, G. M., Hecht, S. S., Felton, J. S., Conney, A. H. and Loeb, L.A., 2004, Environmental and Chemical Carcinogenesis, Semin. Cancer Biol., I4(6), 473-486. 